\title{
Rhizobium mongolense sp. nov. is one of three rhizobial genotypes identified which nodulate and form nitrogen-fixing symbioses with Medicago ruthenica [(L.) Ledebour]
}

\author{
Peter van Berkum, ${ }^{1}$ Desta Beyene, ${ }^{1}$ Guiping Bao, ${ }^{2}$ T. Austin Campbell ${ }^{1}$ \\ and Bertrand D. Eardly ${ }^{3}$
}

1 US Department of Agriculture, ARS, Soybean and Alfalfa Research Laboratory, $\mathrm{HH}-19$, Bldg 011, BARC-West, Beltsville, MD 20705, USA

2 Grasslands Research Institute, Hohehott, People's Republic of China

3 Penn State University, Berks Campus, Tulpohocken Road, Reading, PA, USA
Author for correspondence: Peter van Berkum. Tel: +1 301504 7280. Fax: + 13015045728. e-mail: pberkum@asrr.arsusda.gov

\begin{abstract}
Medicago ruthenica [(L.) Ledebour] is native to Inner Mongolia where rhizosphere samples were collected for the isolation of 106 rhizobial cultures. Besides nodulating the original trap host, the isolates formed nitrogen-fixing symbioses with Phaseolus vulgaris. Only half of the isolates nodulated alfalfa (Medicago sativa), but these did not form nitrogen-fixing symbioses.

Rhizobium tropici also formed nitrogen-fixing symbioses with Medicago ruthenica. A total of $\mathbf{5 6}$ distinctive multilocus electrophoretic types (ETs) were identified among 94 of the 106 isolates which were analysed for variation in electrophoretic mobility of 12 enzyme loci. One isolate (USDA 1920) possessed a unique ET, while the ETs of the other isolates formed two weakly divergent subgroups approximately equal in size. It was concluded from small subunit rRNA gene sequences of eight isolates of Medicago ruthenica that they belonged to the genus Rhizobium and not to the genus Sinorhizobium which is more commonly associated with Medicago. Genomic similarity, determined from DNA hybridization analysis, between USDA 1920 and the strain representing the remaining isolates (USDA 1844) was lower than $20 \%$. Based upon these observations it was concluded that at least three genomic species of rhizobia form nitrogen-fixing symbioses with Medicago ruthenica. One of these genomic species is $R$. tropici, another is represented by the single isolate USDA 1920 and the name Rhizobium mongolense is proposed for the third genomic species represented by USDA 1844.
\end{abstract}

Keywords: Rhizobium mongolense sp. nov., Medicago ruthenica, root-nodule bacteria

\section{INTRODUCTION}

Medicago ruthenica [(L.) Ledebour] is a potential new forage crop and also may be a source of genes for the genetic improvement of cultivated alfalfa (Medicago sativa $\mathrm{L}$.) for tolerance to stress. It grows in Siberia, Mongolia and Manchuria on open hillsides, mixed grass steppes and meadows. Medicago ruthenica, and the closely related Medicago platycarpa, may be remnants of an ancient Arcto-Tertiary complex of flora and may have been the progenitors of other

Abbreviations: ET, electrophoretic type; MAG, modified arabinosegluconate; MLEE, multilocus enzyme electrophoresis; SSU, small subunit.

The GenBank accession numbers for the SSU rRNA gene sequences are U89816-U89832.
Medicago species and Trigonella (1). Medicago ruthenica is a relatively unique species which is adapted to dry locations with cold winters. Its range is very limited compared with the widely cultivated Medicago sativa. Although nodulation of Medicago ruthenica has been reported (31), a detailed description of the characteristics of the rhizobial symbionts has not been made.

The nitrogen-fixing symbionts of legumes, collectively referred to as rhizobia, are genetically diverse bacteria which may occur in soils where legumes grow. Five genera of rhizobia, totalling 18 different species (24) have been characterized. The symbionts of Medicago sativa (alfalfa), classified as Sinorhizobium meliloti, are genetically diverse $(4,7,14)$. Recently, Sinorhizobium medicae has been suggested as an additional species 
which forms symbioses with plants of the genus Medicago (18).

In 1991, a collaborative expedition between the Agricultural Research Service, USDA and the Grassland Research Institute, the People's Republic of China was made to collect seed of Medicago ruthenica from temperate steppes and temperate desert steppes in Inner Mongolia (3). Seed from 105 populations was collected to ensure the presence of genetic diversity in the sample and because this plant has potential for use as a crop in low input sustainable agriculture. A 2-year agronomic evaluation of 50 accessions led to the conclusion that there is considerable genetic variation that could be exploited in a breeding programme to adapt this species to agriculture (3).

Plant-microbe interactions may be highly specific and the collection of exotic legume germplasm from native wild sites also requires collection of rhizosphere samples for the isolation of appropriate rhizobial germplasm. Therefore, rhizosphere samples for the isolation of rhizobia were also collected during the expedition.

The objectives of this work were to isolate the rhizobia from the rhizosphere samples collected during the expedition and to determine their phenotypic and genetic relationships with other species of nitrogenfixing legume symbionts. We concluded that at least three genomic species within the genus Rhizobium form symbioses with Medicago ruthenica.

\section{METHODS}

Plant culture, isolation of symbionts from nodules, and nodulation tests. Seeds of Medicago ruthenica were scarified with sandpaper before they were surface-sterilized with $1 \%$ $\mathrm{NaOCl}$ for $3 \mathrm{~min}$ and rinsed six times with sterile distilled water. The surface-sterilized seeds were germinated by incubation at $30^{\circ} \mathrm{C}$ on sterile water agar for $2 \mathrm{~d}$. Plants were grown in sterilized Leonard jar assemblies (11) containing vermiculite moistened with $300 \mathrm{ml}$ nitrogen-free plant nutrient solution (16). the surface-sterilized seeds were placed in furrows containing approximately $0.25 \mathrm{~g}$ of the rhizosphere samples collected in Inner Mongolia. Plants were grown in a growth chamber as described previously (26). Every nodule from 60 -d-old plants was collected and the rhizobia were isolated according to the method described by Vincent (27). Each isolate was successively purified on modified arabinose-gluconate (MAG) (23) agar plates by streaking from single colonies. Purified cultures were examined for nodulation of Medicago ruthenica and Medicago sativa in sterile Leonard jar assemblies using the same procedure for the isolation of the rhizobia with the exception that the rhizosphere samples were replaced with approximately $10^{9}$ cells of suspension cultures. Specific cultures (USDA 1844, USDA 1904 and USDA 1929) were examined for nodulation of Phaseolus vulgaris, Vicia villosa, Vigna angularis, Vigna unguiculata, Vigna radiata, Pisum sativum, Trifolium pratense, Leucaena leucocephala and Glycine max. Pure cultures, verified for their nodulation ability with Medicago ruthenica, were stored as $50 \%$ glycerol-in-water suspensions at $-70^{\circ} \mathrm{C}$. Subsequently, all the cultures were lyophilized and became part of the USDA ARS National Rhizobium Culture Collection. Working stocks were maintained on MAG slants and were kept at $4{ }^{\circ} \mathrm{C}$ for periods not exceeding one month.

Reference strains used in comparative analyses. The type strains or strains representing a species used in comparative analyses were Bradyrhizobium japonicum, USDA $6^{\mathrm{T}}$; Bradyrhizobium elkanii, USDA $76^{\mathrm{T}}$; Sinorhizobium meliloti, USDA $1002^{\mathrm{T}}$; Sinorhizobium fredii, USDA 205 ; Sinorhizobium saheli, ORS 611; Sinorhizobium teranga, ORS 51; Rhizobium leguminosarum, USDA $2370^{\mathrm{T}}$; Rhizobium etli, CFN $42^{\mathrm{T}}$, Rhizobium tropici, CIAT $899^{\mathrm{T}}$; Rhizobium galegae, HAMBI $540^{\mathrm{T}}$; Mesorhizobium loti, NZP 2213 Mesorhizobium huakuii, CCBAU 2609 $9^{\mathrm{T}}$; Mesorhizobium ciceri, UPM-Ca $7^{\mathrm{T}}$; and Mesorhizobium mediterraneum, UPM-Ca36 ${ }^{\mathrm{T}}$. At the time the analyses were done the type strains for $S$. saheli and $S$. teranga were not available. Additional strains used were $S$. meliloti, USDA 1011, USDA 1021 and USDA $1025 ;$ R. leguminosarum bv. trifolii, USDA 2146 ; $R$. leguminosarum bv. viciae, USDA 2377 , USDA 2399, USDA 2434, USDA 2443, USDA 2449, USDA 2498, USDA 2501 and USDA 2508; $R$. leguminosarum bv. phaseoli, RCR 3644; and R. tropici, CFN 299.

Multilocus enzyme electrophoresis (MLEE). Techniques used for starch-gel electrophoresis and the selective staining of enzymes have been described previously $(6,7,19)$. The electrophoretic buffer systems and the 12 enzymes assayed were as follows: Tris citrate ( $\mathrm{pH} \mathrm{6.7)}$ for 6-phosphogluconate dehydrogenase (6PG) and aconitase (ACO); Tris citrate $(\mathrm{pH} \mathrm{8.0)}$ for NAD-malate dehydrogenase (MDH), phosphoglucose isomerase (PGI), isocitrate dehydrogenase (IDH), glucose-6-phosphate dehydrogenase (G6P), leucylalanine peptidase (PEP) and xanthine dehydrogenase $(\mathrm{XDH})$; borate $(\mathrm{pH} \mathrm{8.2)}$ for indophenol oxidase (IPO), hexokinase (HEX), adenylate kinase (ADK) and phosphoglucomutase (PGM). Distinctive mobility variants (electromorphs) of each enzyme, numbered in order of decreasing anodal mobility, were equated with alleles at the corresponding structural gene locus. Allele profiles or electrophoretic types (ETs) were equated with multilocus genotypes. The genetic distance between pairs of ETs was estimated as the proportion of loci at which dissimilar alleles (mismatches) occurred. Clustering of ETs from a matrix of pairwise genetic distances was performed by the unweighted pair group method (20). Genetic diversity $(h)$ at an enzyme locus was calculated as $h=\left[1-\Sigma x_{i} 2\right][n /(n-1)]$, where $x_{i}$ is the frequency of the $i$ th allele at the locus and $n$ is the number of ETs in the population. The extent of linkage disequilibrium (non-random combinations of alleles) among ETs was estimated by comparing observed and expected moments of allelic mismatch frequency distributions (29). An 'index of association' or $\mathrm{I}_{\mathrm{A}}$, originally described by Brown et al. (2), was used to demonstrate a non-random association of alleles. Equations for the calculation of $I_{A}$ and its associated error variance are described by Maynard Smith et al. (14); briefly, $I_{A}$ is calculated by subtracting one from the ratio of the observed-to-expected mismatch distribution variances for a particular sample. The expected value of $I_{A}$ for a single large random mating population is zero, while values of $I_{A}$ that differ significantly from zero indicate that assortative recombination has been rare in the population. Programs for the analysis of genetic diversity, ET clustering and linkage disequilibrium were written by T. S. Whittam (Pennsylvania State University).

Phenotypic characterization of the isolates. Representative cultures identified by MLEE ( 56 cultures) and an additional six isolates were tested for resistance, by growth on MAG, to the presence of ampicillin, bacitracin, cefuperazone, 
Table 1. Description of the sites where seeds of Medicago ruthenica were collected and where rhizosphere samples originated for the isolation of the nitrogen-fixing symbionts

\begin{tabular}{|c|c|c|c|c|}
\hline Location & Soil pH & $\begin{array}{c}\text { Legumes on the site besides } \\
\text { M. ruthenica }\end{array}$ & $\begin{array}{l}\text { No. of } \\
\text { isolates }\end{array}$ & USDA accession nos \\
\hline $\begin{array}{l}\text { Daqing Valley, } \\
\text { Tongliao }\end{array}$ & $6 \cdot 4-7 \cdot 1$ & $\begin{array}{l}\text { Lespedeza bicolor } \\
\text { Astragalus spp. }\end{array}$ & 17 & $\begin{array}{l}\text { USDA } 1830-1831 \\
\text { USDA } 1844-1848 \\
\text { USDA } 1865-1874\end{array}$ \\
\hline Huhehot & $6 \cdot 4-7 \cdot 5$ & $\begin{array}{l}\text { Caragana intramongolica } \\
\text { Medicago sativa } \\
\text { Potentilla spp. }\end{array}$ & 7 & $\begin{array}{l}\text { USDA } 1832 \\
\text { USDA } 1875-1876 \\
\text { USDA } 1888-1891\end{array}$ \\
\hline Xilinhot & $6 \cdot 4-7 \cdot 6$ & $\begin{array}{l}\text { C. intramongolica } \\
\text { Medicago sativa } \\
\text { Medicago falcata }\end{array}$ & 12 & $\begin{array}{l}\text { USDA } 1833-1842 \\
\text { USDA } 1877-1878\end{array}$ \\
\hline $\begin{array}{l}\text { Shiaoqing Valley, } \\
\text { Tongliao }\end{array}$ & $6 \cdot 8-6 \cdot 9$ & $\begin{array}{l}\text { L. bicolor } \\
\text { Astragalus } \mathrm{spp} . \\
\text { Trifolium sibericum }\end{array}$ & 16 & USDA $1849-1864$ \\
\hline Hutan Lan & $6 \cdot 6$ & Astragalus adsurgens & 9 & USDA $1879-1887$ \\
\hline $\begin{array}{l}\text { Ecological Reserve, } \\
\text { Xilinhot }\end{array}$ & $6 \cdot 4-7 \cdot 4$ & $\begin{array}{l}M . \text { sativa, } M . \text { falcata } \\
\text { A. adsurgens } \\
\text { C. intramongolica }\end{array}$ & 44 & USDA $1892-1935$ \\
\hline
\end{tabular}

cefuroxime, ciprofloxacin, novobiocin, penicillin $\mathrm{G}$, polymyxin $B$, streptomycin and tetracycline by using the agar diffusion disc method (Difco). Zones of inhibition were measured over a 7-d period for each disc. Resistance was scored when the inhibition zones were less than $2 \mathrm{~mm}$. Inhibition zones greater than $2 \mathrm{~mm}$ were considered to indicate sensitivity to each of the antibiotics (10). The same 62 cultures were used to investigate utilization of sole carbon substrates in MAG basal medium (without yeast extract) supplemented with different carbon sources at final concentrations of $0.2 \%$ (10) and bromothymol blue at $0.005 \%$. The basal medium was sterilized by autoclaving before the addition of filter-sterilized carbon substrate solution. The $\mathrm{pH}$ of each growth medium was adjusted to $\mathrm{pH} 7 \cdot 0$ with $1 \mathrm{M}$ $\mathrm{HCl}$ using the bromothymol blue as an indicator. The carbon substrates tested were: sodium acetate, sodium citrate, sodium malate, sodium malonate, maltose, sorbose, sodium saccharate and $\mathrm{D}$-fructose. The basal medium with the addition of sodium gluconate $(0.1 \%)$ and arabinose $(0 \cdot 1 \%)$ was used as a positive control, while basal medium without the addition of a carbon substrate was used as a negative control. Each isolate was streaked to single colonies to score growth after $7 \mathrm{~d}$ at $30^{\circ} \mathrm{C}$. A positive score was assigned to a carbon substrate when growth of the single colonies was similar to those on the positive control plates supplemented with sodium gluconate and arabinose. A similar procedure was used to investigate utilization of amino acids as sole nitrogen source. The basal medium was supplemented with arabinose and sodium gluconate and each amino acid was added to a final concentration of $10 \mathrm{mM}$. The amino acids tested were: arginine, glycine, lysine, methionine, phenylalanine, threonine, tryptophan and tyrosine. Positive scores were assigned to amino acids when the growth with the amino acid supplement was equal to that of control plates supplemented with $0.1 \%$ yeast extract. Additional tests included tolerance to $\mathrm{NaCl}$ at concentrations of $0 \%$ (control) $0.5 \%, 1.0 \%, 2.0 \%$ and $3.0 \%$ using YEM medium (27). The reaction to litmus milk was examined by using Difco litmus milk medium. Flagellation of the USDA 1844 culture was determined with isolated colonies grown on solid MAG medium. The bacterial cells were placed on grids and left to settle for $2 \mathrm{~h}$ before they were stained with $4 \%(\mathrm{w} / \mathrm{v})$ uranyl acetate for $5 \mathrm{~min}$ in preparation for transmission electron microscopy according to the methods of Roland (17).

Preparation of DNA and DNA-DNA reassociation. Cultures of the isolates and strains of rhizobia were grown in $50 \mathrm{ml}$ MAG broth (23) until mid-exponential phase for the extraction of DNA. Genomic DNA was extracted from washed cell suspensions and was purified by $\mathrm{CsCl}$ centrifugation as described previously (15). Samples $(10 \mu \mathrm{g})$ of DNA were digested with the restriction endonuclease EcoRI for the determination of DNA homology according to the method of van Berkum et al. (25).

PCR amplification and sequence analysis of the small subunit (SSU) rRNA gene. Colonies of the bacteria were grown on the surface of MAG medium and were placed in $200 \mu$ portions of $0.1 \%$ Tween 20 and the cells were lysed by incubating the suspensions at $95^{\circ} \mathrm{C}$ for $10 \mathrm{~min}$. Samples $(4 \mu \mathrm{l})$ of these lysed cell suspensions were used in $120 \mu \mathrm{l}$ PCR mixtures containing primers $\mathrm{fD} 1$ and $\mathrm{rDl}$ (28). PCR conditions for the amplification of the SSU rRNA genes were as described previously (25). The PCR products were purified by using QIAquick spin columns (Qiagen) and both strands were sequenced by using a model 370A DNA sequencer (Applied Biosystems) as described by van Berkum et al. (25).

Analysis of the sequence data. The sequences were aligned using the PILEUP program in the Wisconsin package of the Genetics Computer Group (Madison, WI, USA). Aligned sequences were analysed using the SEQBOOT, DNADIST, NEIGHBOR and CONSENSE programs of the software package PHYLIP version $3.5 \mathrm{c}(8)$ and trees were constructed using RETREE and DRAWGRAM. Additional analyses were made using the Molecular Evolutionary Genetics Analysis (MEGA) package version 1.01 (9) to derive the nucleotide sequence similarities of the SSU rRNA genes.

Nucleotide sequence accession numbers. The SSU rRNA gene sequences of the $R$. tropici type strain CIAT 899 , the isolates from Medicago ruthenica: USDA 1832, USDA 1834, 
USDA 1836, USDA 1844, USDA 1877, USDA 1890, USDA 1920 and USDA 1929; the strains from Pisum sativum: USDA 2377, USDA 2399, USDA 2434, USDA 2443 and USDA 2449; and the strains from Vicia faba: USDA 2498, USDA 2501 and USDA 2508 have GenBank accession numbers U89832, U89816, U89818, U89819, U89817, U89820, U89821, U89823, U89822, U89824, U89825, U89826, U89827, U89828, U89829, U89830, and U89831, respectively.

\section{RESULTS}

Rhizosphere samples used as inoculants for seedlings of Medicago ruthenica were obtained from six different locations in Inner Mongolia. Isolations were made from every nodule on the roots of 60-d-old plants, which resulted in the collection of 106 cultures (Table 1). Visual observations of plant size and foliage colour compared with uninoculated controls after $60 \mathrm{~d}$ growth were used to classify the symbiotic potential of each isolate with the original trap host. Of the 106 isolates included in the test, 22 were classified as poor because plants were either yellow or no larger than the uninoculated controls. Sixty eight isolates nodulated Medicago sativa, producing from a few to many nodules per plant. However, none of these 68 isolates were capable of nitrogen fixation with alfalfa, since all 60-d-old plants were yellow and small, similar to the uninoculated controls. The selected strains USDA 1844, USDA 1904 and USDA 1929 nodulated Phaseolus vulgaris, Vicia villosa and Vigna angularis, but all these associations with the exception of those with Phaseolus vulgaris were ineffective. Pisum sativum, Trifolium pratense, Leucaena leucocephala, Vigna unguiculata, Vigna radiata and $G$. max were not nodulated. S. meliloti strains USDA $1002^{\mathrm{T}}$, USDA 1011, USDA 1021a and USDA 1025 nodulated Medicago ruthenica, but the associations did not fix

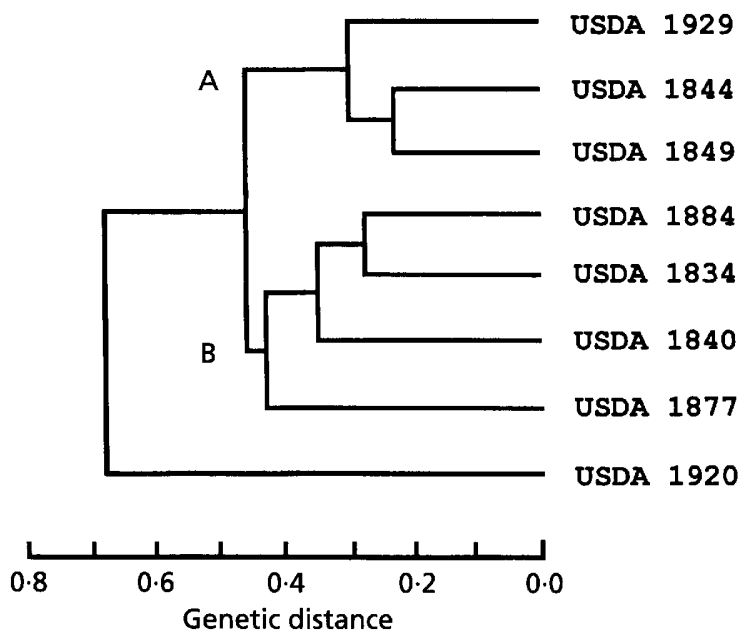

Fig. 1. Genetic relationships among eight representative ETs (of 56 total) observed among rhizobial isolates from Medicago ruthenica. The USDA strain number for one isolate representing each ET is listed.

nitrogen. $R$. tropici strains CIAT 899 and CFN 299 formed effective nitrogen-fixing symbioses with Medicago ruthenica with acetylene reduction rates of 1.9 and $6.6 \mu \mathrm{mol} \mathrm{C}_{2} \mathrm{H}_{4}$ per plant $\mathrm{h}^{-1}$ and dry matter accumulation of 0.3 and $0.6 \mathrm{~g}$ per plant, respectively. By comparison, these values were $10.3,9.6,14.6$ and $0 \mu \mathrm{mol} \mathrm{C}_{2} \mathrm{H}_{4}$ per plant $\mathrm{h}^{-1}$ and $0 \cdot 9,0 \cdot 9,1 \cdot 0$ and $0 \cdot 1 \mathrm{~g}$ per plant for plants inoculated with USDA 1844 , USDA 1904, USDA 1929 and the uninoculated control, respectively. The type strains of $R$. etli, $B$. japonicum and $B$. elkanii and the reference strain of $R$. leguminosarum bv. phaseoli (RCR 3644) did not nodulate Medicago ruthenica.

Of the 106 isolates, 95 were analysed for variation in

Table 2. Allele profiles at 12 enzyme loci for eight representative ETs (of 56 total) of the symbionts of Medicago ruthenica

Allele profiles for all 94 isolates (56 ETs) are available from B.D.E. upon request. The following isolates were not included in the MLEE analysis: USDA 1830, USDA 1831, USDA 1832, USDA 1836, USDA 1843, USDA 1874, USDA 1890, USDA 1895, USDA 1901, USDA 1902, USDA 1904, USDA 1906.

\begin{tabular}{|lllllllllllllll|}
\hline Isolate & \multicolumn{10}{c|}{ Allele at the indicated locus:* } \\
\cline { 2 - 12 } & ACO & 6PG & IDH & G6P & MDH & IPO & ADK & HEX & PGM & PGI & PEP & XDH \\
\hline USDA 1834 & 1 & 3 & 3 & 1 & 1 & 2 & 2 & 2 & 2 & 1 & 4 & 3 \\
USDA 1840 & 2 & 3 & 3 & 1 & 1 & 2 & 2 & 2 & 1 & 2 & 4 & 2 \\
USDA 1844 & 1 & 2 & 3 & 1 & 1 & 2 & 4 & 3 & 2 & 1 & 2 & 3 \\
USDA 1849 & 1 & 2 & 3 & 1 & 1 & 2 & 4 & 1 & 2 & 1 & 2 & 3 \\
USDA 1877 & 2 & 3 & 1 & 1 & 1 & 2 & 1 & 2 & 2 & 1 & 1 & 2 \\
USDA 1884 & 3 & 3 & 3 & 1 & 1 & 2 & 2 & 2 & 2 & 2 & 3 & 2 \\
USDA 1920 & 1 & 1 & 2 & 2 & 1 & 1 & 4 & 4 & 2 & 3 & 3 & 1 \\
USDA 1929 & 1 & 2 & 3 & 1 & 1 & 2 & 3 & 4 & 2 & 1 & 2 & 3 \\
\hline
\end{tabular}

* For definitions of enzymes, see Methods. 


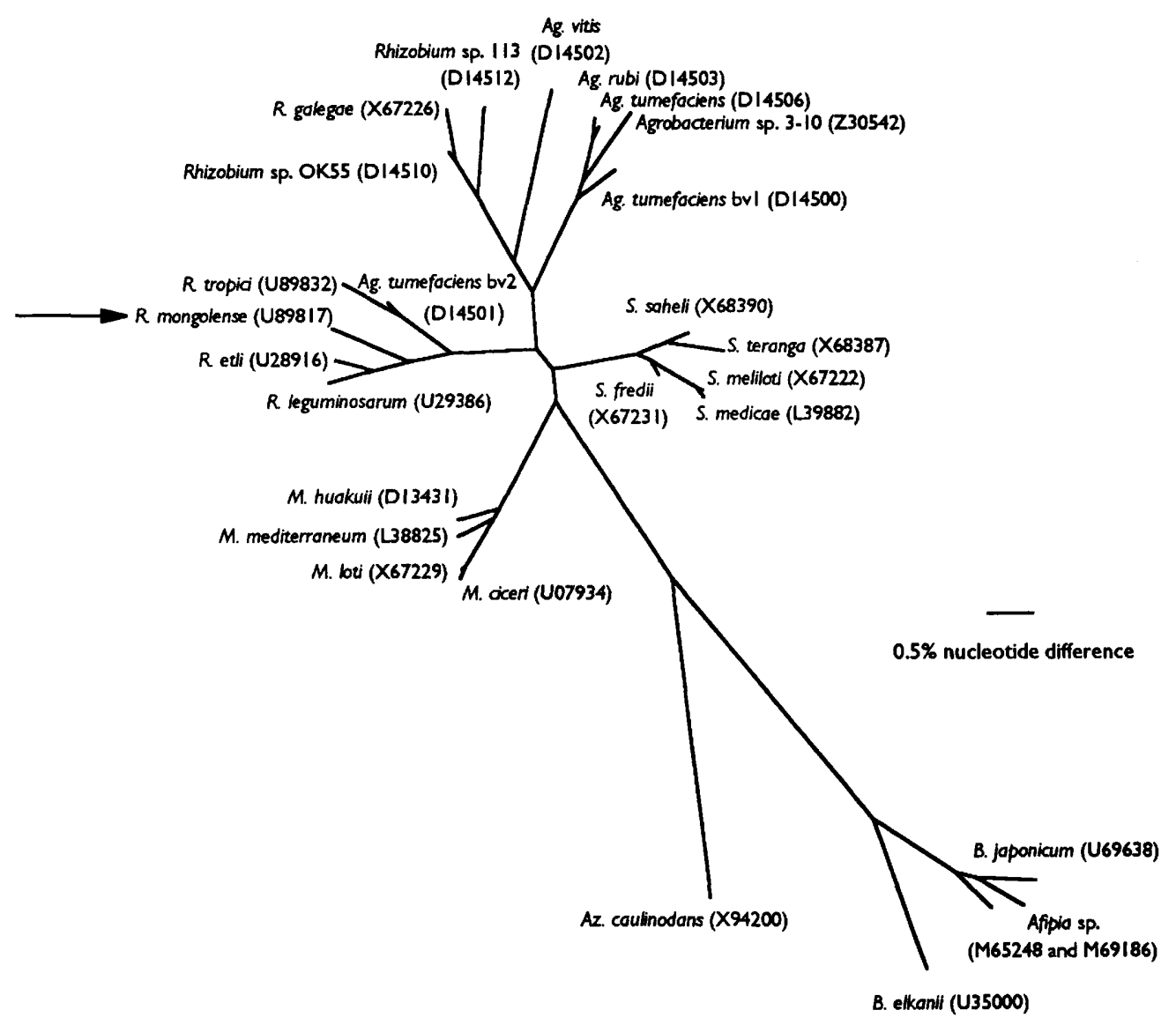

Fig. 2. Phylogenetic relationship of Rhizobium mongolense within the $\alpha$-subdivision of the Proteobacteria based upon aligned sequences of the small subunit ribosomal genes. Jukes-Cantor distances were derived from the aligned sequences to construct an unrooted tree using the neighbour-joining method. Reported sequences of representative members within the $\alpha$-subdivision that were used are indicated in parentheses. The sequences were aligned and analysed and the tree was constructed as described in Methods.

electrophoretic mobility of 12 enzyme loci (the additional isolates, listed in the legend to Table 2, were not available at the time of the analysis). A total of 56 distinctive multilocus ETs were identified. The type strains for the different species were initially included in the analysis, but they were subsequently excluded because they each shared less than three electromorphs (genetic distance $>0.75$ ) with the isolates (data not shown). Forty-eight of these ETs were represented by one or two isolates, while the largest number of isolates in any single ET was twelve, represented by USDA 1844 (Table 2). With the exception of malate dehydrogenase, the enzymes were polymorphic, because the variability ranged from two to five alleles per locus. The $h$ values per enzyme locus were 0.04-0.74 with an overall mean diversity per locus $(H)$ of $0 \cdot 38$.

Allelic profiles for eight ETs were chosen to represent the range of multilocus genotypic diversity observed among the isolates (Table 2) and a dendrogram illustrating the relative genetic distance among these eight ETs is shown in Fig. 1. We observed from the cluster analysis one strongly divergent ET (represented by the single isolate, USDA 1920), and two less divergent subgroups (labelled A and B). Subgroup A, represented by USDA 1929, USDA 1844 and USDA 1849 , consisted of 50 isolates and contained 27 ETs. Subgroup B, represented by USDA 1884, USDA 1834 , USDA 1840 and USDA 1877 , consisted of 43 isolates and contained 29 ETs (data not shown).

The observed variance of the ET mismatch distribution for the entire set of 56 ETs was significantly larger than expected $\left(\mathrm{I}_{\mathrm{A}}=0.84 \pm 0.18\right)$, implying a clonal population structure among the chromosomal lineages. The disparity between the observed and estimated variances was narrowed $\left(I_{A}=0.69 \pm 0.18\right)$, without a concomitant increase in error variance, by the removal of the most divergent ET (that of USDA 1920) from the data set. Further subdivision of the remaining ETs into subgroups $A$ and $B$ resulted in $I_{A}$ values $(0 \cdot 16 \pm 0 \cdot 25$ and $0 \cdot 12 \pm 0 \cdot 26$, respectively) that did not differ significantly from zero.

Additional phylogenetic information about the isolates from Medicago ruthenica was obtained with sequencing analysis of the SSU rRNA genes. The SSU rRNA nucleotide sequences of USDA 1844 and USDA 1920 were aligned for a comparison with the 


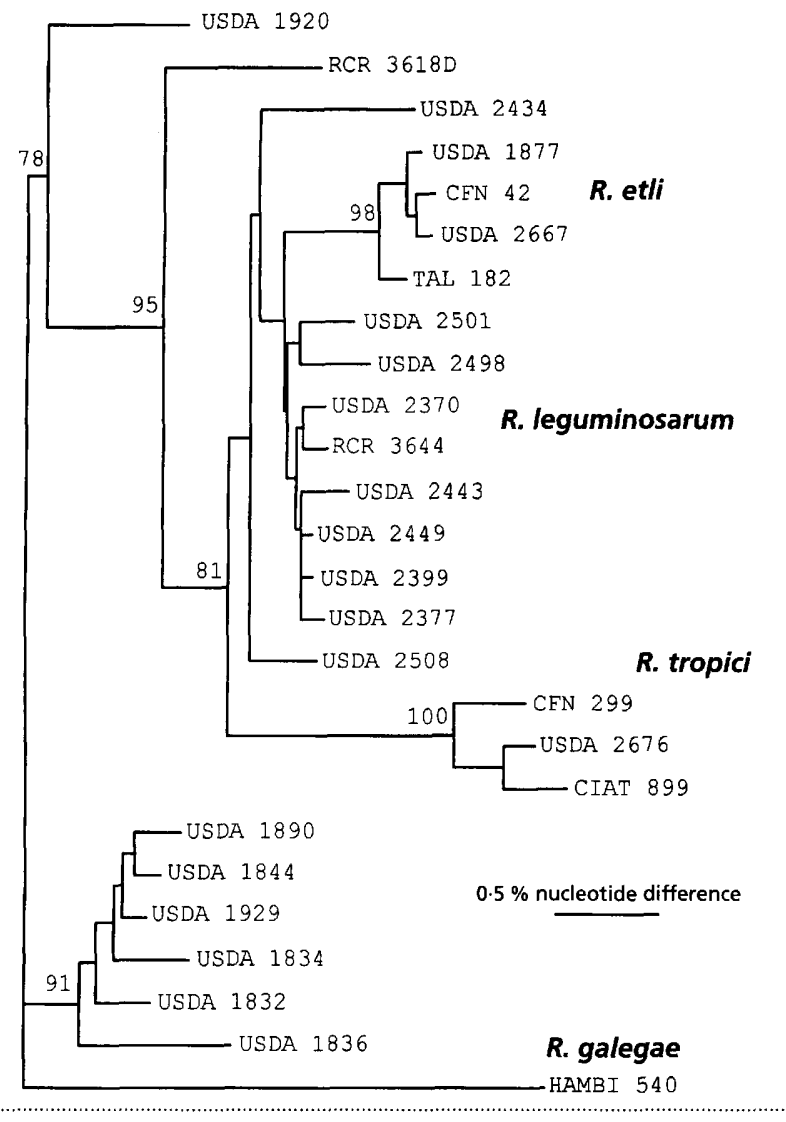

Fig. 3. Phylogenetic relationship of Rhizobium mongolense (including USDA 1877) and USDA 1920 within the genus Rhizobium based upon aligned sequences of the small subunit ribosomal RNA genes. Jukes-Cantor distances were derived from the aligned sequences to construct an optimal unrooted tree using the neighbour-joining method. One thousand replicate trees were generated in a bootstrap analysis to derive a majority rule consensus tree. The levels of support exceeding $75 \%$ for the presence of nodes are indicated in the tree. Reported sequences used in the phylogenetic analysis were those of: $R$. leguminosarum bv. viciae (USDA 2370, U29386), $R$. leguminosarum bv. phaseoli (RCR 3644, U29388), R. etli (CFN 42, U28916; TAL 182, U28939; USDA 2667, U47303), $R$. tropici (CFN 299, X67234; USDA 2676, U38469), Rhizobium Sp. (RCR 3618D, U29387) and $R$. galegae (X67226). The sequences were aligned and the aligned sequences were analysed as described in Methods.

SSU rRNA nucleotide sequences of the reference strains of the legume symbionts. The comparison led to the conclusion that the SSU rRNA genes of these two isolates were most similar to the SSU rRNA genes of $R$. etli because SSU rRNA gene sequence similarities with the type strain CFN 42 were 98.3 and $98.1 \%$, respectively. This compared with SSU rRNA gene sequence similarities of 97.7 and $97.8 \%$, respectively, with the type strain of $R$. leguminosarum (USDA 2370) and 96.5 and $96.4 \%$, respectively, with the type strain of $R$. tropici (CIAT 899). SSU rRNA gene sequence similarities between USDA 1844 and the type strains of Agrobacterium, NCPPB 2997 (A. tumefaciens bv. 2, GenBank accession no. D14501), NCPPB 1854 ( $A$. rubi, D14503), NCPPB 1650 (A.tumefaciens, D14506),
NCPPB 2437 (A. tumefaciens bv. 1, D14500) and NCPPB 3554 (A. vitis, D14502) were 97.0, 94.6, 94.6, 95.5 and $95.0 \%$, respectively. In contrast, these values with USDA 1920 were $96 \cdot 9,95 \cdot 5,95 \cdot 5,96 \cdot 5$ and $95 \cdot 0 \%$, respectively. The branch point of the type strain for $R$. mongolense, USDA 1844, was between the clusters formed by the type strains for $R$. etli and $R$. leguminosarum and those for $R$. tropici and $A$. tumefaciens bv. 2 (Fig. 2). The SSU rRNA gene sequences of an additional seven isolates from Medicago ruthenica and eight strains of Pisum sativum and Vichia faba were determined and were used to construct a phylogenetic tree within the genus $R h i$ zobium. Five of the isolates clustered together with USDA 1844 and formed a node separate from the other 20 strains (Fig. 3). The isolates USDA 1920 and USDA 1877 did not cluster with the isolates originating from Medicago ruthenica. The isolate USDA 1920 formed a separate node by itself while USDA 1877 was nested within the cluster formed by three strains of $R$. etli. The SSU rRNA nucleotide sequences of USDA 1920 and USDA 1877 were 98.5 and $98.3 \%$ similar to the sequences of USDA 1844. The SSU rRNA nucleotide sequences of USDA 1877 and $R$. etli (CFN 42) were $99.7 \%$ similar.

Genomic similarities between the isolates from Medicago ruthenica and strains representing other genera and species of nitrogen-fixing legume symbionts were estimated from results of DNA hybridization. DNA relatedness of USDA 1844 and of USDA 1920 with 13 additional isolates ranged from 11 to $86 \%$ and from 4 to $5 \%$, respectively (Table 3 ). The values of DNA hybridization among the three isolates USDA 1844, USDA 1877 and USDA 1920 were low. Levels of DNA relatedness of $R$. etli $\left(\mathrm{CFN} 42^{\mathrm{T}}\right)$ and $R$. leguminosarum (USDA $2370^{\mathrm{T}}$ ) with 14 isolates from Medicago ruthenica ranged from 6 to $21 \%$ and from 8 to $26 \%$, respectively (Table 3 ). The levels of DNA relatedness of USDA 1844 with the reference strains USDA $6^{\mathrm{T}}$, USDA $76^{\mathrm{T}}$, USDA $205^{\mathrm{T}}$, USDA $1002^{\mathrm{T}}$, ORS 611, ORS 51, NZP 2213 ${ }^{\mathrm{T}}$, CCBAU $2609^{\mathrm{T}}$, UPM$\mathrm{Ca}^{\mathrm{T}}$, UPM-Ca36 ${ }^{\mathrm{T}}$, USDA $2370^{\mathrm{T}}$, USDA 2146 , RCR 3364, CFN 42 ${ }^{\mathrm{T}}$, CIAT 899 ${ }^{\mathrm{T}}$, CFN 299 and HAMBI $540^{\mathrm{T}}$ were $3,3,9,5,2,5,3,3,4,2,10,8,8,9,8,9$ and $6 \%$, respectively, while the values with USDA 1920 were $3,2,5,4,3,4,3,3,3,3,11,5,11,6,5,5$ and $5 \%$, respectively.

The phenotypic characteristics of the rhizobial isolates from Medicago ruthenica were determined with 56 isolates, each representing an ET by MLEE, and an additional six isolates which had not been included. The phenotypic characters of USDA 1844 and USDA 1920 compared with the type strains of $R$. leguminosarum, $R$. etli, $R$. tropici, $R$. galegae, $S$. meliloti, $S$. fredii, Mesorhizobium loti and Mesorhizobium huakuii are presented in Table 4. Also indicated are the number of positive scores for each of the parameters determined with 62 isolates. Individual antibiotics could not be used to distinguish USDA 1844 or USDA 1920 from the type strains. However, a combination of 
Table 3. Levels of DNA relatedness between isolates from Medicago ruthenica and those from $R$. leguminosarum and $R$. etli determined by DNA-DNA hybridization analysis

\begin{tabular}{|cccccr|}
\hline & \multicolumn{5}{c}{ Percentage DNA relatedness with: } \\
& USDA 1844 & USDA 1920 & USDA 1834 & CFN 42 & USDA 2370 \\
\hline USDA 1831 & 85 & 5 & ND & 8 & 9 \\
USDA 1832 & 74 & 5 & ND & 11 & 9 \\
USDA 1834 & 53 & 5 & 100 & 6 & 10 \\
USDA 1836 & 36 & 5 & 96 & 7 & 8 \\
USDA 1840 & 49 & 5 & 84 & 7 & 8 \\
USDA 1844 & 100 & 4 & 68 & 11 & 8 \\
USDA 1849 & 54 & 5 & 88 & 11 & 11 \\
USDA 1874 & 65 & 5 & ND & 11 & 13 \\
USDA 1877 & 22 & 4 & 17 & 21 & 26 \\
USDA 1884 & 86 & 5 & ND & 7 & 17 \\
USDA 1890 & 53 & 5 & 30 & 6 & 11 \\
USDA 1904 & 71 & 5 & ND & 6 & 9 \\
USDA 1920 & 11 & 100 & ND & 20 & 10 \\
USDA 1929 & 69 & 4 & ND & 7 & 11 \\
\hline
\end{tabular}

ND, Not determined.

resistance to cefuperazone and penicillin $G$ and sensitivity to ciprofloxacin did distinguish these two isolates from the type strains. The isolates USDA 1844 and USDA 1920 could not be distinguished from the type strains by growth or absence of growth with any single amino acid. However, a combination of growth with methionine, threonine and tyrosine distinguished the type strains and these two isolates. Growth of USDA 1844 and USDA 1920 with sodium acetate as sole carbon substrate distinguished these two isolates and the type strains. Growth with sodium acetate as sole carbon substrate appeared to be a distinguishing characteristic for the isolates since 54 of the 62 cultures gave positive scores. USDA 1863, USDA 1864, USDA 1874, USDA 1875, USDA 1876, USDA 1877, USDA 1879, USDA 1880 and USDA 1933 did not grow with sodium acetate as sole carbon substrate. Of the 62 isolates three were sensitive to $\mathrm{NaCl}, 28,28$ and 3 grew with up to $0.5,1.0$ and $>1.0 \% \mathrm{NaCl}$, respectively. All the isolates had a positive reaction with the litmus milk test. Bacterial cells of isolate USDA 1844 had a single polar or sub-polar flagellum (Fig. 4).

\section{DISCUSSION}

The ability of Medicago ruthenica to nodulate is evident from a report by Wipf (31), who described chromosome number in nodules and root tips of different species within four plant genera. Although Medicago ruthenica was a plant species included in that study, no information about nodulation and nitrogen fixation nor of the characterization of the rhizobia was reported or has been described since the study of Wipf (31). We describe the isolation and characterization of the rhizobia of Medicago ruthenica, and communicate nodulation studies with this host plant.
Members of the family Rhizobiaceae are distinguishable by the production of hypertrophies on higher plants. Within the Rhizobiaceae, the majority of isolates belonging to genera of the legume symbionts and the genus Agrobacterium are distinguished phenotypically by the nature of the plant-microbe interaction. However, many legume symbionts cannot be differentiated because phenotypic differences, including host plant affinity (30), are often not sufficiently distinctive.

One of the most popular approaches used to estimate phylogenetic relationships among bacteria is the determination of the genetic distance in the nucleotide sequence of the SSU rRNA genes (12). We concluded from our analysis that the isolates from Medicago ruthenica are most closely related to rhizobial species within the genus Rhizobium. This inference is in contrast to the phylogeny of the rhizobial symbionts of other plants within the genus Medicago, which are nodulated by bacteria belonging to the genus Sinorhizobium $(4,18)$.

From the SSU rRNA data it may be concluded that all but two of the isolates belonged to a single species because their ribosomal genes were almost identical. Although the SSU rRNA gene sequences of isolates USDA 1877 and USDA 1920 were the more divergent, all were more than $97 \%$ similar to those of $R$. etli and $R$. leguminosarum. Stackebrandt \& Goebel (21) indicated that additional information in the form of DNA-DNA reassociation values is required to define species limits when SSU rRNA gene sequences are similar by more than $97 \%$. Therefore, additional criteria were used to help define the species limits among the isolates we examined. However, additional information about several species within the genus 
Table 4. Phenotypic characterization of USDA 1844 and USDA 1920 compared with selected type strains

\begin{tabular}{|c|c|c|c|c|c|c|c|c|c|c|c|c|}
\hline & $\begin{array}{c}\text { USDA } \\
1844\end{array}$ & $\begin{array}{c}\text { USDA } \\
1920\end{array}$ & $\begin{array}{c}R . \\
\text { leguminosarum }\end{array}$ & R. etli & $\begin{array}{c}R . \\
\text { tropici } \\
\text { IIA }\end{array}$ & $\begin{array}{c}R . \\
\text { tropici } \\
\text { IIB }\end{array}$ & $\begin{array}{c}R . \\
\text { galegae }\end{array}$ & $\begin{array}{c}S . \\
\text { meliloti }\end{array}$ & $\begin{array}{c}S . \\
\text { fredii }\end{array}$ & M. loti & $\begin{array}{c}M . \\
\text { huakuii }\end{array}$ & $\begin{array}{l}\text { Positive } \\
\text { scores } \dagger\end{array}$ \\
\hline Bacitracin & $\mathrm{R}^{*}$ & $\mathrm{R}$ & $\mathrm{R}$ & S & $\mathrm{R}$ & $\mathrm{R}$ & $S$ & $S$ & $S$ & $\mathbf{R}$ & $S$ & 51 \\
\hline Cefuperazone & $\mathrm{R}$ & $\mathrm{R}$ & $\mathrm{S}$ & $\mathrm{S}$ & $\mathrm{S}$ & $\mathbf{R}$ & $\mathbf{R}$ & $\mathrm{S}$ & $\mathrm{S}$ & $\mathrm{R}$ & $\mathrm{S}$ & 55 \\
\hline Cefuroxime & $\mathrm{R}$ & $\mathrm{S}$ & $\mathrm{S}$ & $\mathrm{S}$ & $\mathrm{S}$ & $\mathrm{R}$ & $\mathrm{S}$ & $\mathrm{S}$ & $\mathrm{R}$ & $\mathrm{R}$ & $\mathrm{S}$ & 10 \\
\hline Novobiocin & $\mathrm{s}$ & $\mathrm{s}$ & $\mathrm{S}$ & $\mathrm{S}$ & $S$ & $\mathrm{~S}$ & $\mathrm{~S}$ & $\mathrm{R}$ & $\mathrm{S}$ & $\mathrm{S}$ & $\mathrm{S}$ & 6 \\
\hline Polymyxin B & $\mathrm{S}$ & $\mathrm{R}$ & $\mathrm{S}$ & $\mathrm{S}$ & $\mathrm{S}$ & $\mathbf{R}$ & $\mathrm{R}$ & $\mathrm{S}$ & $\mathrm{S}$ & $\mathrm{R}$ & $\mathrm{S}$ & 8 \\
\hline Ampicillin & $\mathrm{S}$ & $\mathrm{R}$ & $\mathrm{S}$ & $\mathrm{S}$ & $\mathrm{S}$ & $\mathbf{R}$ & $\mathrm{S}$ & $\mathrm{S}$ & $\mathrm{S}$ & $\mathrm{S}$ & $\mathrm{S}$ & 24 \\
\hline Ciprofloxacin & $\mathrm{S}$ & $\mathrm{S}$ & $\mathrm{S}$ & $\mathrm{S}$ & $\mathrm{S}$ & $\mathbf{R}$ & $\mathrm{S}$ & $\mathrm{S}$ & $\mathbf{R}$ & $\mathrm{S}$ & $\mathrm{S}$ & 2 \\
\hline Penicillin G & $\mathbf{R}$ & $\mathrm{R}$ & $\mathrm{S}$ & $\mathrm{S}$ & $\mathrm{S}$ & $\mathbf{R}$ & $\mathrm{S}$ & $\mathrm{S}$ & $\mathrm{R}$ & $\mathrm{S}$ & $\mathrm{S}$ & 57 \\
\hline Streptomycin & $\mathrm{S}$ & $\mathrm{R}$ & $\mathrm{S}$ & $\mathbf{R}$ & $\mathrm{S}$ & $\mathbf{R}$ & $\mathrm{S}$ & $\mathrm{S}$ & $\mathrm{S}$ & $\mathrm{S}$ & $\mathbf{R}$ & 5 \\
\hline Tetracycline & $\mathrm{S}$ & $\mathrm{S}$ & $\mathrm{S}$ & $\mathrm{S}$ & $\mathrm{S}$ & $\mathrm{S}$ & $\mathrm{S}$ & $\mathrm{S}$ & $\mathrm{S}$ & $\mathrm{S}$ & $\mathrm{S}$ & 0 \\
\hline Malate & + & + & - & - & - & + & + & - & + & + & + & 48 \\
\hline Malonate & - & - & - & - & - & + & + & - & + & - & - & 26 \\
\hline Sorbose & - & - & + & + & + & + & - & + & + & - & + & 11 \\
\hline Saccharic acid & - & - & - & + & - & + & + & - & - & - & + & 10 \\
\hline Fructose & + & + & + & + & + & + & + & + & + & + & + & 62 \\
\hline Maltose & + & + & - & + & + & + & - & + & - & + & - & 62 \\
\hline Acetate & + & + & - & - & - & - & - & - & - & - & - & 54 \\
\hline Citrate & + & - & - & - & - & + & - & - & - & - & + & 16 \\
\hline Arginine & + & - & - & - & - & + & + & - & + & + & + & 53 \\
\hline Glycine & - & - & - & - & - & + & - & + & - & - & + & 13 \\
\hline Methionine & + & + & + & - & - & - & - & - & - & - & + & 24 \\
\hline Phenylalanine & - & + & - & - & - & + & - & + & + & - & - & 44 \\
\hline Threonine & + & + & + & - & - & - & - & - & - & - & - & 29 \\
\hline Tryptophan & + & - & - & - & - & + & - & + & + & - & + & 19 \\
\hline Tyrosine & + & + & - & - & - & + & - & + & + & - & + & 36 \\
\hline Lysine & + & - & - & + & - & + & - & + & + & + & + & 51 \\
\hline $\begin{array}{l}\mathrm{NaCl} \text { tolerance } \\
(\%)\end{array}$ & 0 & $1 \cdot 0$ & 0 & 0.5 & 1.0 & $2 \cdot 0$ & $1 \cdot 0$ & $2 \cdot 0$ & $1 \cdot 0$ & $1 \cdot 0$ & $1 \cdot 0$ & \\
\hline
\end{tabular}

* R, Resistant; S, sensitive; +, positive; - , negative.

$\dagger$ Number of positive scores with 62 isolates from Medicago ruthenica.

Agrobacterium was not obtained because their SSU rRNA gene sequences with USDA 1844 and USDA 1920 were equal to or less than $97 \%$.

From the DNA reassociation data we concluded that the genomic similarity of USDA 1844 and USDA 1920 with the type strains representing the different genera and species of legume symbionts was low. Genomic similarity of USDA 1877 with the type strains for $R$. etli and $R$. leguminosarum was equally low, which would support a conclusion for three species from the SSU rRNA data. However, DNA-DNA hybridization and SSU rRNA sequence analysis may not always provide accurate estimates of evolutionary relationships. Dykhuizen \& Green (5) have suggested that a better approach might be to apply a biological species concept where a species is defined as a group of strains that share a common gene pool. Speciation based on DNA-DNA hybridization has been criticized because species limits are arbitrarily defined points on a continuum (13), and also because this method cannot account for genomic partitioning or the product of recombination. Therefore, we used MLEE analysis in an attempt to establish groups of isolates which shared gene pools and to establish whether we could identify genetic exchange with any of the type strains of the legume symbionts.

We infer from the MLEE data a history of recombination among the members of each of the subgroups $A$ and $B$, but the increase in error variance that accompanied subdivision makes this conclusion equivocal. Furthermore, separation of the two subgroups would be contrary to the results obtained from DNA hybridization. Because of the absence of strong evidence for linkage disequilibrium in each subgroup the individual ETs (or branches) in these groups (Fig. 1) should not be interpreted as representing independently evolving phylogenetic lineages. On the basis of these results we concluded that the subdivision of the members of this collection into more than two species would not be wholly justified. We also concluded that these two genomic species do not represent any previously described rhizobial species because 

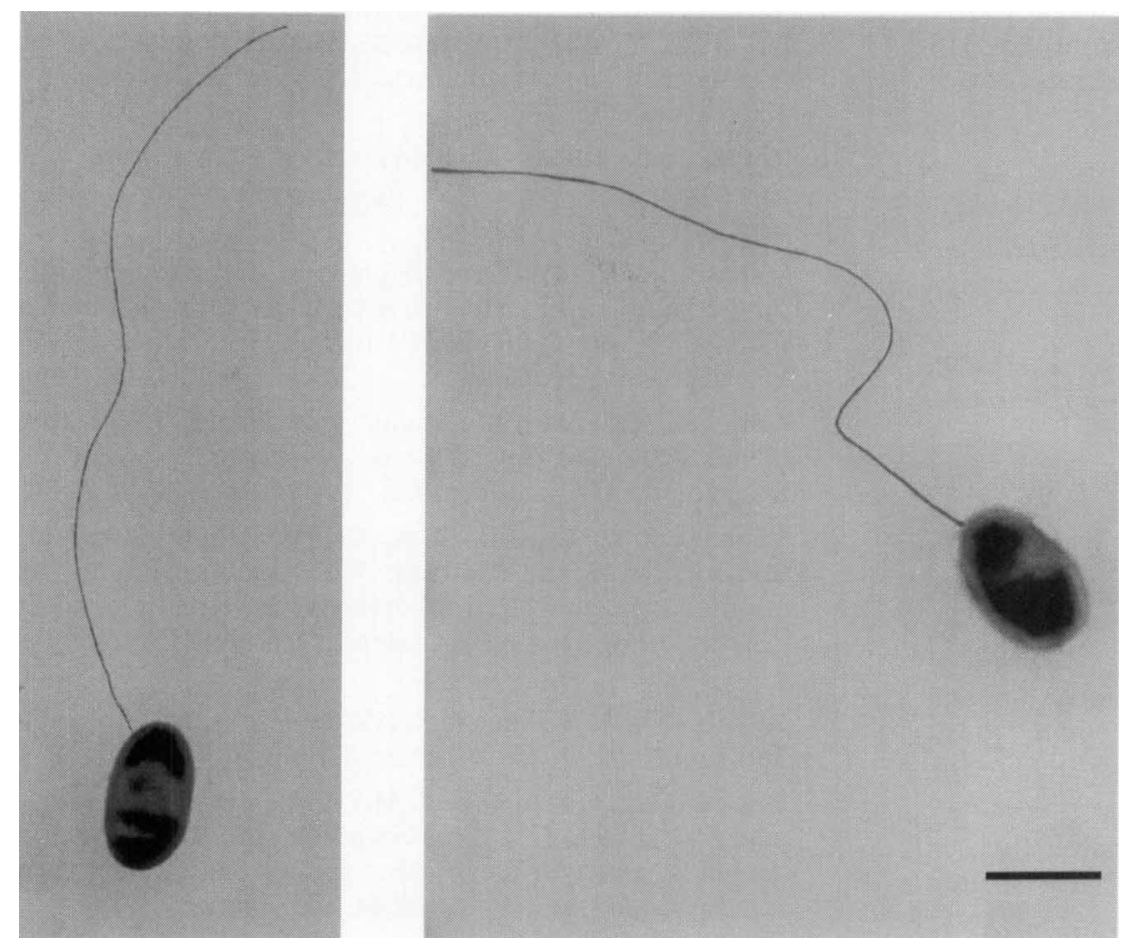

Fig. 4. Electron micrographs of the type strain of Rhizobium mongolense, USDA 1844. Colonies used for analysis were grown for $3 \mathrm{~d}$ at $30^{\circ} \mathrm{C}$ on the surface of MAG medium. Bacterial cells placed on grids were stained with $4 \%$ uranyl acetate for $5 \mathrm{~min}$ before transmission electron microscopy (17). Bar, $1 \mu \mathrm{m}$.

type strains of named rhizobial species shared less than three electromorphs with the isolates.

These results and other reports of population genetic studies of the Rhizobiaceae are important since they provide useful criteria for the taxonomic placement of rhizobial isolates. For example, we identified three major lineages which form nitrogen-fixing symbioses with Medicago ruthenica. The first of these was $R$. tropici, the second was represented by the single isolate USDA 1920 and the third, represented by USDA 1844 , included all the remaining isolates we examined. In this third species we provisionally included USDA 1877 , based solely on the MLEE data. However, it is important to note that neither the DNA hybridization results nor the SSU rRNA sequence comparisons support the placement of this strain. It seems possible that the unusual MLEE profile of USDA 1877 may be the result of recombination between two or more rhizobial lineages. Sullivan et al. (22) have indicated that the occurrence of chromosomal recombination between species may be significant in natural populations of rhizobia. If this is indeed the case, our difficulty in placing USDA 1877 may reflect a broader problem in rhizobial systematics, which is the placement of chimeric genotypes.

\section{Description of Rhizobium mongolense sp. nov.}

Rhizobium mongolense (mŏng'gə.len'se. L. adj. mongolense referring to Inner Mongolia, the region in the People's Republic of China from where the bacteria originated).

Gram-negative, aerobic non-spore-forming rods which are motile by a single polar or sub-polar flagellum. Colonies on MAG are circular, elevated, white opaque, appearing in $3-5 \mathrm{~d}$ at $30^{\circ} \mathrm{C}$ when they are $1-3 \mathrm{~mm}$ in diameter. Bacteria produce acid on YEM. Growth on YEM is inhibited between 0 and $1 \%$ $\mathrm{NaCl}$ and below $\mathrm{pH} 4 \cdot 0$. Strains are generally resistant to bacitracin, cefuperazone and penicillin $G$, utilize sodium acetate, fructose, sodium malate and maltose as sole carbon substrates for growth, and utilize arginine and lysine as sole nitrogen substrates for growth. Strains were isolated from nodules of Medicago ruthenica, which is native to open hillsides, mixed grass steppes and meadows of Siberia, Mongolia and Manchuria. The strains nodulate Medicago ruthenica and Phaseolus vulgaris. The strains can be distinguished by SSU rRNA gene sequences, by DNA homology and by distinctive multilocus electrophoretic types. The type strain is USDA 1844 , which has the characteristics given above for the species.

After this manuscript was accepted for publication we became aware of the proposal for the new species Rhizobium gallicum and Rhizobium giardinii originating from bean nodules growing in French soils (Amarger, N., Macheret, V. \& Laguerre, G. (1997) Rhizobium gallicum sp. nov. and Rhizobium giardinii sp. nov., from Phaseolus vulgaris nodules. Int J Syst Bacteriol 47, 996-1006). The SSU rRNA gene sequences of the type strains for $R$. gallicum and $R$. mongolense are $99 \cdot 2 \%$ similar.

\section{ACKNOWLEDGEMENTS}

The authors express their appreciation to R. K. Selander for providing facilities and supplies for the MLEE analysis, to Charlie Murphy for electron microscopy, and to $\mathrm{K}$. Lee 
Nash for technical assistance. This work was partly supported by grant OICD 60-32U4-3-277 from the US Department of Agriculture, Agricultural Research Service and the Foreign Agricultural Service.

\section{REFERENCES}

1. Balabaev, G. A. (1934). Yellow lucernes of Siberia, Medicago ruthenica (L.) Lebd. and M. platycarpos (L.) Lebd. Bull App Bot Genet Plant Breed Serv 7, 113-123.

2. Brown, A.H. D., Feldman, M. W. \& Nevo, E. (1980). Multilocus structure of natural populations of Hordeum spontaneum. Genetics 96, 523-536.

3. Campbell, T. A., Bao, G. \& Xia, Z. L. (1997). Agronomic evaluation of Medicago ruthenica collected in Inner Mongolia. Crop Sci 37, 599-604.

4. De Lajudie, P., Willems, A., Pot, B., Dewettinck, D., Maestrojuan, G., Neyra, M., Collins, M. D., Dreyfus, B., Kersters, K. \& Gillis, M. (1994). Polyphasic taxonomy of rhizobia: emendation of the genus Sinorhizobium and description of Sinorhizobium meliloti comb. nov., Sinorhizobium saheli sp. nov., and Sinorhizobium teranga sp. nov. Int $J$ Syst Bacteriol 44, 715-733.

5. Dykhuizen, D. E. \& Green, L. (1991). Recombination in Escherichia coli and the definition of biological species. $J$ Bacteriol 173, 7257-7268.

6. Eardly, B. D. (1994). Multilocus enzyme electrophoresis methods for the analysis of bacterial population genetic structure. In Methods of Soil Analysis, part 2, Microbiological and Biochemical Properties, pp. 557-573. Edited by R. W. Weaver, J. S. Angle \& P. J. Bottomley. Madison, WI: Soil Science Society of America.

7. Eardly, B. D., Materon, L. A., Smith, N. H., Johnson, D. A., Rumbaugh, M. D. \& Selander, R. K. (1990). Genetic structure of natural populations of the nitrogen-fixing bacterium Rhizobium meliloti. Appl Environ Microbiol 56, 187-194.

8. Felsenstein, J. (1993). PHYLIP (phylogenetic inference package), version 3.5c. Department of Genetics, University of Washington, Seattle, USA.

9. Kumar, S., Tamura, K. \& Nei, M. (1993). MEGA: Molecular Evolutionary Genetics Analysis, version 1.01. The Pennsylvania State University, University Park, PA 16802 , USA.

10. Ladha, J. \& So, R. B. (1994). Numerical taxonomy of photosynthetic rhizobia nodulating Aeschynomene species. Int J Syst Bacteriol 44, 62-73.

11. Leonard, L. T. (1943). A simple assembly for use in the testing for cultures of rhizobia. J Bacteriol 45, 523-527.

12. Maidak, B. L., Larsen, N., McCaughey, M. J., Overbeek, R. Olsen, G. J., Fogel, K., Blandy, J. \& Woese, C. R. (1994). The ribosomal database project. Nucleic Acids Res 22 , 3485-3487.

13. Maynard Smith, J. (1995). Do bacteria have population genetics? In Population Genetics of Bacteria, pp. 1-12. Edited by S. Baumberg, J. P. W. Young, E. M. H. Wellington \& J. R. Saunders. Cambridge: Cambridge University Press.

14. Maynard Smith, J., Smith, N. H., O'Rourke, M. \& Spratt, B. J. (1993). How clonal are bacteria? Proc Natl Acad Sci USA 90, 4384-4388.
15. Navarro, R. B., Vargas, A. A. T., Schröder, E. C. \& van Berkum, P. (1993). Uptake hydrogenase (Hup) in common bean (Phaseolus vulgaris) symbioses. Appl Environ Microbiol 59, $4161-4165$.

16. Norris, D. O. (1964). Techniques used in the work with Rhizobium. Commonw Bur Pastures Field Crops Hurley Berkshire Bull 47, 186-198.

17. Roland, J.-C. (1978). General preparation and staining of thin sections. In Electron Microscopy and Cytochemistry of Plant Cells, pp. 1-66. Edited by J. L. Hall. Amsterdam: Elsevier/North-Holland.

18. Rome, S., Fernandez, M., Brunel, B., Normand, P. \& CleyetMarel, J.-C. (1996). Sinorhizobium medicae sp. nov., isolated from annual Medicago spp. Int J Syst Bacteriol 46, 972-980.

19. Selander, R. K., Caugant, D. A., Ochman, H., Musser, J. M., Gilmour, M. N. \& Whittam, T. S. (1986). Methods of multilocus enzyme electrophoresis for bacterial population genetics and systematics. Appl Environ Microbiol 51, 873-884.

20. Sneath, P. H. A. \& Sokal, R. R. (1973). Numerical Taxonomy. San Francisco: W. H. Freeman \& Sons.

21. Stackebrandt, E. \& Goebel, R. M. (1994). Taxonomic note: a place for DNA-DNA reassociation and $16 \mathrm{~S}$ rRNA sequence analysis in the present species definition in bacteriology. Int J Syst Bacteriol 44, 846-849.

22. Sullivan, J. T., Eardly, B. D., van Berkum, P. \& Ronson, C. W. (1996). Four unnamed species of nonsymbiotic rhizobia isolated from the rhizosphere of Lotus corniculatus. Appl Environ Microbiol 62, 2818-2825.

23. van Berkum, P. (1990). Evidence for a third uptake hydrogenase phenotype among the soybean bradyrhizobia. Appl Environ Microbiol 56, 3835-3841.

24. van Berkum, P. \& Eardly, B. D. (1998). Molecular evolutionary systematics of the Rhizobiaceae. In The Rhizobiaceae: Molecular Biology of Model Plant-associated Bacteria. Edited by H. P. Spaink, A. Kondorosi \& P. J. J. Hooykaas. Dordrecht: Kluwer (in press).

25. van Berkum, P., Beyene, D. \& Eardly, B. D. (1996). Phylogenetic relationships among Rhizobium species nodulating the common bean (Phaseolus vulgaris L.). Int $J$ Syst Bacteriol 46, 240-244.

26. van Berkum, P., Tully, R. E. \& Keister, D. L. (1995). Nonpigmented and bacteriochlorophyll-containing bradyrhizobia isolated from Aeschynomene indica. Appl Environ Microbiol 61, 623-629.

27. Vincent, J. M. (1970). A Manual for the Practical Study of Root-nodule Bacteria. International Biological Programme, Handbook no. 15. Oxford: Blackwell.

28. Weisburg, W. G., Barns, S. M., Pelletier, D. A. \& Lane, D. J. (1991). 16S ribosomal DNA amplification for phylogenetic study. $J$ Bacteriol 173, 697-703.

29. Whittam, T. S., Ochman, H. \& Selander, R. K. (1983). Multilocus genetic structure in natural populations of Escherichia coli. Proc Natl Acad Sci USA 80, 1751-1755.

30. Wilson, J. K. (1944). Over five hundred reasons for abandoning the cross-inoculation groups of the legumes. Soil Sci 58, 61-69.

31. Wipf, L. (1939). Chromosome numbers in root nodules and root tips of certain Leguminosae. Bot Gaz 101, 51-67. 